\title{
Depositional Trends and Sedimentary Environments of the Cenomanian-Turonian Sediments along G. Nezzazat-G. Ekma, South-West Sinai, Egypt
}

\author{
Farouk M. El Fawal, Hatem F. Hassan and Amer A. Shehata \\ Geology Department, Faculty of Science, Port Said University, Port Said, Egypt.
}

\begin{abstract}
The Upper Cretaceous sedimentary succession at G. Nezzazat-G. Ekma, west-central Sinai was examined to detect the depositional trends responsible for its development and discuss the depositional sedimentary environments dominated its evolution. The examined succession spanning from early Cenomanian to Turonian age and consists of three rock units namely from the base; Raha, Abu Qada and Wata formations. The detailed lithological and sedimentological characteristics of the concerned succession revealed that Raha Formation has been subdivided into Abu Had Member and Mellaha Sand Member and diagnostically characterized by the presence of both three clastic and three non clastic microfacies association on the other hand, Abu Qada Formation is characterized also by three clastic and four non clastic microfacies association which indicates deposition of both in a mixed siliciclastic- carbonate system on a ramp setting, whereas Wata Formation is characterized by the dominance of non clastic microfacies. All the recorded microfacies association is described and their sedimentary environments are concluded. The Raha Formation was deposited under progressively advancing subtle sea that reached maximum by the mid-parts of the formation and retreated toward the top part of the formation. Abu Qada Formation was deposited under successively advancing sea started in shallow foreshore conditions and continued deepening toward the top of the formation where outer marine shelf facies dominated. Whereas, the Wata Formation is represents a phase of relatively deep marine sedimentation, mostly within mid-outer marine shelf setting.
\end{abstract}

Keywords: Cenomanian-Turonian, Depositional trends, Sedimentary environment, Sinai.

\section{Introduction}

During the Cenomanian- Turonian time, Sinai was a part of the Afro-Arabian plate [10]. The position of Egypt at that time was $10^{\circ}$ north of the Equator, within the low latitude belts $\left(20^{\circ}\right.$ north and south) that are primary sites for carbonate production [3]. Sinai was a broad carbonate shelf with episodic intercalations of siliciclastic deposits on the passive margin of the southern Tethys Sea [9]. While the Syrian arc- structures tectonically controlled the deposition and depict the basins geometry in North Sinai, South Sinai was tectonically stable throughout this time ([39]; [28]). The Cenomanian rocks in Egypt are generally characterized as being deposited by an overall transgressive sea. In northern Sinai, the Cenomanian rocks are mainly represented by carbonates while in the southern parts, siliciclastic predominate [34]. The Turonian rocks conformably overlie the Cenomanian rocks and are unconformably overlain the Coniacian rocks. The Cenomanian- Turonian rocks in west central Sinai are represented by three formations; the Raha, Abu Qada and Wata formations [22]. Most studies of the Cenomanian-Turonian (C-T) sequences of Egypt have concentrated on biostratigraphy and faunal turnovers based on macrofossils (ammonites) and microfossils (foraminifera, nannofossils), and very few dealt with the environmental and paleoceanographic changes ([31]; [33]; [25]; [32]; [30]; [26]; [9]; [27]).

This study aimed to investigate the different depositional sedimentary environments within which the Cenomanian- Turonian sediments were evolved in the study area. The evolution of each rock unit will be emphasized according to the progressive development of the depositional environments influencing its evolution. The present work is ground on the basis of detailed lithostratigraphic and microlithofacies analyses for the Cenomanian- Turonian rocks in G. Nezzazat - Ekma Block, west-central Sinai, which enable the depositional interpretation of both paleo-sedimentary during this time interval.

\section{Study Area:}

The study area (Fig. 1) extends beside the western coast of the Gulf of Suez, encompassing two famous mountains; G. Nezzazat to the north, and G. Ekma to the south, laying between Lat.:28 $47^{\prime} 13^{\prime \prime} \& 28^{\circ} 40^{\prime} 22.6^{\prime \prime} \mathrm{N}$

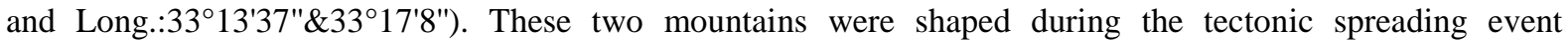
associated with the opening of the Red Sea and the Gulf of Suez by late Oligocene [21]. The mountains are located about $150 \mathrm{~km}$ and $165 \mathrm{~km}$ southeast of Suez City respectively along NW-oriented fault blocks with a general trend parallel to the Gulf of Suez (Fig.1). The two blocks are $11.0 \mathrm{~km}$ apart with an average width of 4.0 
$\mathrm{km}$ at G. Nezzazat and $7.0 \mathrm{~km}$ at G. Ekma. They are bounded to the north by Baba plain and to the south by G. Abu Durba.

\section{METHODS:}

To achieve the above mentioned objectives, a detailed field studies were made including the examination of the Upper Cretaceous successions cropping-out in G. Nezzazat - G. Ekma stretch. Across each Gable, a lithologic profile was detected passing through the complete lithostratigraphic units of the Upper Cretaceous sediments. In each profile, detailed examination of the bed geometries, bed contacts, lithological vertical variations, sedimentary structures and paleocurrents. The unconformity surfaces and the criteria of sea shallowing and/or coastal emergence (hard grounds, duricrusts, tepees, etc.) were recorded. Careful sampling for each bed encountered in the sedimentary succession is then carried-out where a number of 200 representative spot samples were chosen representing the sedimentary facies in the Upper Cretaceous sediments examined. These samples were analyzed for their bulk textural composition and grain-size characteristics to arrive the accurate lithologic characteristics of the examined successions. Moreover, a number of thirty eight (38) thin sections were prepared for the microlithofacies examination and determination of the depositional sedimentary environments of the examined rock units.

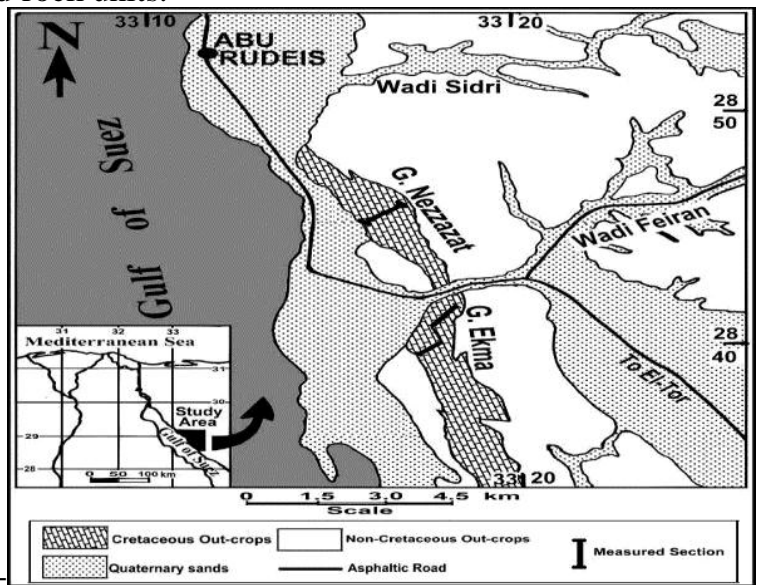

(Fig. 1): Location map of the studied Cenomanian- Turonian rock units. (Reproduced after [43]).

\section{Lithostratigraphy Of The Cenomanian-Turonian Sediments:}

Based upon the detailed field studies and the facies characteristics of the exposed Upper Cretaceous sediments in G. Nezzazat - G. Ekma, it is concluded that the Upper Cretaceous sediments are differentiated into five rock units, namely from the base; the Raha Formation, Abu Qada Formation and Wata Formation, ranging in age from Cenomanian to Turonian. The concerned succession rests over the famous Lower Cretaceous Malha Formation (Fig.2a) of [1].In the study area, the Malha Formation consists of thick sandstone beds with siltstone and claystone interbeds, commonly barren of marine fauna. Its base is unexposed, whereas the upper contact between with the Cenomanian sediments is easily marked due to the obvious variation in sediment geometricalstyle, sediment-stacking regime and the presence of marine fauna characteristic of the Cenomanian; Ilymatogyra africana, Ceratostreon flabellatum, Ceratostreon (Costagyrai) olisiponensis. The following is a description of the Upper Cretaceous rock units exposed in the study area, from older to younger units:-

\subsection{Raha Formation}

The Raha Formation was first identified by [22] to describe $120.0 \mathrm{~m}$ thick of shale, sandstone and limestone beds of the Cenomanian age at its type locality in the scarp of the Raha Plateau, west-central Sinai. In the study area, the Raha Formation conformably overlies the Lower Cretaceous Malha Formation and conformably underlies the shale of Abu Qada Formation. The present Raha Formation consists of a succession of shale, limestone, and a few sandstone beds (Fig.2a). It attains $55.0 \mathrm{~m}$ thick at G. Nezzazat and $63.0 \mathrm{~m}$ thick at G. Ekma.

Lithologically, [22] distinguished two members within the Raha Formation in the type area; the lower one is Abu Had Member and the upper is Mellaha Sand Member. In the study area, [22] subdivisions were clearly recognized in the examined Raha Formation as follows:-

\subsubsection{Abu Had Member:}

This member is represented by $46.0 \mathrm{~m}$ thick at G. Nezzazat and $52.0 \mathrm{~m}$ thick at G. Ekma. It is composed of yellowish green fissile glauconitic shale, displaying sheet geometry and sharp contacts. These shales are interbedded with a few limestone interbeds, especially in the western parts. This member is rich in the 
characteristic Cenomanian fossils. It is of worth mentioning that the lithology of the present Abu Had Member grades eastward into more clastic-rich facies, especially in the lower levels at G. Ekma.

\subsubsection{Mellaha Sand Member:}

This member is conformably overlies Abu Had Member. It consists of hard, dark brown units of ferruginous sandstone with thin shale interbeds. The thickness of this member varies from $8.0 \mathrm{~m}$ thick at $\mathrm{G}$. Nezzazat to $11.0 \mathrm{~m}$ at G. Ekma.

The Raha Formation is commonly characterized by typical Cenomanian fossils. In the study area, the following fossil assemblages have been recorded; Thomasenella aegyptia (Omara), Thomasenella punica (Schlumberger), Cribrostomoides sinaica (Omara), Nezzazata simplex (Omara), Ilymatogyra africana (Fawzi), Ilymatogyra aegyptiaca (Fawzi), Ceratostreon flabellatum (Goldfuss), Ceratostreon conicata (Fawzi), Ceratostreon involuta (Seguenza) and Exogyra (Costagyrai) olisiponensis (Sharpe). Based upon the faunal assemblage, the Raha Formation is assigned Cenomanian age.

The Raha Formation has many equivalent rock-units in the surrounding areas. In southern Negev; it is termed as Hazera Formation [48]. In North-Sinai; it is termed as Halal Formation [40], whereas in the western side of the Gulf of Suez it referred to as Galala Formation [1].

\subsection{Abu Qada Formation (Upper Cenomanian-Lower Turonian)}

The term Abu Qada Formation was first introduced by [22] to describe $15.0-24.0 \mathrm{~m}$ thick succession of brown to very dark grey marls at Wadi Abu Qada, West-central Sinai. In the study area, Abu Qada Formation conformably overlies the Mellaha Sand Member of the Raha Formation (Fig. 2b), and conformably underlies the Wata Formation. It attains $43.0 \mathrm{~m}$ at G. Nezzazat and $40.0 \mathrm{~m}$ at G. Ekma. The formation in the study area can be subdivided upon its fossil-content into a lower part of Upper Cenomanian age, and an upper part of Lower Turonian age. The Upper Cenomanian part is $27.0 \mathrm{~m}$ thick at G. Nezzazat and $15.0 \mathrm{~m}$ thick at G. Ekma. It yields many Cenomanian fossils, including; Thomasenella aegyptia (Omara), Thomasenella punica (Schlumberger), Thomasenella fragmentaria (Omara), Ismailia neumannae (El Dakkak), Exogyra (Costagyrai) overwegi (Sharpe), and the ostracods: Veeniacythereis jezzineensis (Bischoff), Bairdia pseudosetentrionalis (Mertens) and Bairdia Cenomanica (Babinot). On the other hand, the overlying Lower Turonian part, is $16.0 \mathrm{~m}$ thick at G. Nezzazat and is $25.0 \mathrm{~m}$ thick at G. Ekma. It includes Turonian fossils (ammonites: Metioceras sp., Vascoceras sp., Choffaticeras (Leoniceras) segne (Solger), and Thomasites mesli (Pervinquiere). Based upon the above faunal assemblage, Abu Qada Formation is assigned Upper Cenomanian-Lower Turonian age. It is of worth mentioning that the Cenomanian-Turonian boundary is herein stated by the first appearance of the ammonite Choffaticeras (Leoniceras) segne (Solger).

Abu Qada Formation has many equivalent rock-units in the surrounding areas. In southern Negev and east Sinai it is equivalent to Ora Shales ([5]; [6]; [7]). In other parts of Sinai and North Eastern Desert, it is reported in many localities having the same nomenclature of Abu Qada ([22]; [1]; [30]; [29]; [45]).

\subsection{The Wata Formation (Middle to Upper Turonian):}

The term Wata Formation was first introduced by [22] to describe $55.0 \mathrm{~m}$ thick hard siliceous dolomitic limestone of Turonian age in its type locality at Wadi Wata, Raha Plateau, West-Central Sinai. In the study area, the formation conformably overlies Abu-Qada Formation and conformably underlies the Matulla Formation (Fig.2c). It attains $44.0 \mathrm{~m}$ thick at G. Nezzazat and $37.0 \mathrm{~m}$ thick at G. Ekma. The formation is generally composed of a thick succession of alternating limestones and shales, however, the limestones are more frequent in the upper half.

The Wata Formation in the study area is relatively poor in macrofossils; however some undefined bivalves are present. On the other hand, rare deformed benthonic foraminifera are reported. The softer parts of Wata Formation contain Discorbis turonicus and Nezzazatinella aegytiaca of Middle to Late Turonian age [22]. [24] described the Turonian ostracod Neocyprideis vandenboldi / Cythereis madaourensis assemblage zone from this formation at Gulf of Suez. [28] reported that the upper part of Wata Formation contain the Turonian gastropod Nerinea requieniana (D'Orbigny). Regarding to the age of Wata Formation, it was dated as Lower to Middle Turonian at West Sinai ([2]; [54]), and it is dated as Upper Turonian according to [8], [9], [38]. In addition, the Wata Formation is dated to Middle-Late Turonian acoording to ([22]; [50]; [6], [7]; [31]; [28]; [45], [46]; [47]; [30]; [41]; [42]; [29]; [34]). Based upon the above discussion and the stratigraphic position of the Wata Formation, a Middle-Late Turonian age is suggested.

The Wata Formation has many equivalent rock-units in the surrounding areas. In southern Negev and Eastern Sinai, it is equivalent to Gerofit Formation [48]. In Sinai and North Eastern Desert, it is recorded in many parts and in the subsurface having the same nomenclature ([22]; [1]; [30]; [38]; [45]; [52]). 


\subsection{Thickness and lithological considerations of the Cenomanian-Turonian rock units in the study area:}

The comparative investigations of the rock units forming the Cenomanian-Turonian succession in the study area reveal that there are no marked differences between the examined successions of G. Nezzazat and G. Ekma. The thickness of the Cenomanian-Turonian succession at G. Nezzazat is $150.0 \mathrm{~m}$ and that of G. Ekma is $\sim 140.0 \mathrm{~m}$. The stratigraphic cross-section (Fig. 3) reveals that the examined Raha, Abu Qada and Wata formations almost display uniform thicknesses with no noticeable differences. This implies that the examined rock units were deposited over a tectonically stable open passive margin of the Upper Cretaceous Tethys. This tectonic status helped receiving the deposits over the entire basin in rather homogeneous distribution without remarkable variations in lithology due to the absence of effective tectonic disturbances. However, the relatively high sand-content recorded in G. Ekma can be explained in terms of the situation of G. Ekma close to the eastern high-shoulder of the clastic-rich Lower Cretaceous Malha Formation and the Paleozoic rocks. These neighbours contributed the adjacent younger basins (Upper Cretaceous) with successive clastic-rich loads.

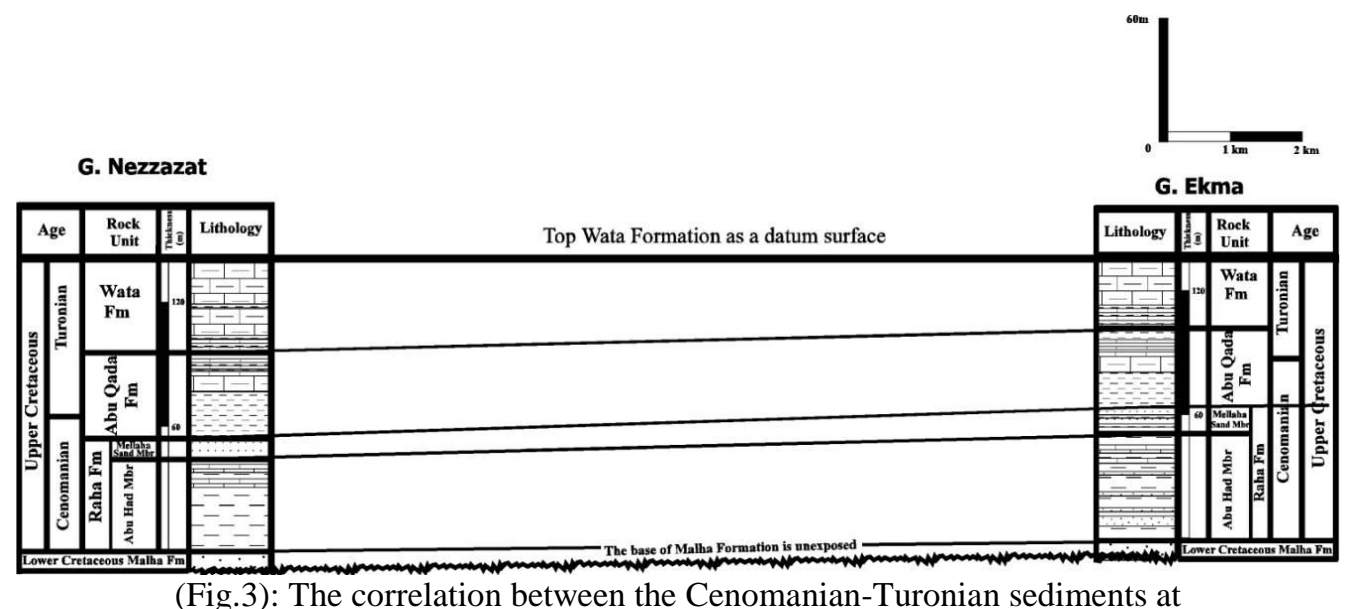

G. Nezzazat and G. Ekma successions.

\section{Microfacies Analysis:}

The petrographic classification of limestone suggested by [18] and [19], the textural classification proposed by [12] and modified by [15], as well as the energy index of [35] were adopted herein. The compositionally and texturally similar microfacies reflecting the possible similar depositional setting within the same formation are herein grouped as "microfacies association" with definite name. These associations were then compared with the standard microfacies types (SMF) and standard facies zones (FZ) of [53] and [16] and [17].

\subsection{The Raha Formation:}

The microscopic investigation of eleven thin sections representing the Raha Formation exposed at G. Nezzazat and G. Ekma revealed six microfacies associations:

\subsubsection{Clastic microfacies associations:-}

\subsubsection{Supratidal-intertidal gypsiferous feldspathic quartz arenite}

This microfacies is recorded at the uppermost part of Raha Formation. It consists of $3.0 \mathrm{~m}$ thick, hard sandstones, exhibiting sheet geometry with planar erosional bed-contacts. Petrographically, the association is composed of dominant $(80-85 \%)$ quartz grains. These grains are medium to fine grained, medium sorted, subangular to subrounded. They are of medium to close packing and display different point, long and concaveconvex grain-to-grain contacts indicating differential burial compaction. The majority of quartz grains are of monocrystalline type with even to slightly wavy extension. Alkali fresh feldspar grains are scattered between the quartz grains constituting $15-7 \%$ of the detritals. A few scattered detritals glauconitic grains are occasionally seen. The different rock components are embedded in a binding material of a minor amount of clays deposited with a dominant crystalline cement of yellowish grey gypsum. This gypsum is seen forming wide patches throughout the components. Deep brown ferruginous materials are seen as a secondary cementation phase that corrodes and dissolve much of the quartz grain boundaries.

The lithologic composition and the petrographical characteristics of this association assume deposition as successive terrestrial loads laid-into a warm evaporitic coastal supratidal/ intertidal flat under marked shallow marine conditions. 


\subsubsection{Supratidal-intertidal Dolomitic quartz arenite association}

This microfacies is recorded at the lower and upper parts of the Raha Formation. It consists of hard, compact, sheet-like beds of brown sandstone beds vary in thickness from $1.0 \mathrm{~m}$ to about $4.0 \mathrm{~m}$ thick. They intercalate with shale beds at the upper parts. Petrographically, the association is composed of quartz grains forming $85 \%-90 \%$ of the total rock volume. The quartz grains are of fine to medium grain size, poorly sorted, and subangular-subrounded. These grains display medium packing where the majority of the grains show no grain-to-grain contacts, except a few point contacts. The majority of quartz grains are of monocrystalline type with even and slightly wavy extension. These detrital sands are embedded in an original cement of well developed dolomite crystal rhombs having pale brown colour, forming 10-15\% of the facies components, indicating active role of Mg-rich marine water resulted in the development of the coarse crystalline dolomite cement. This cement strongly corrodes the boundaries of the quartz detritals.

The field geometry and stacking-style as well as the petrographic characteristics of this association together with the absence of any fossil remains or even their traces suggest deposition within a warm, saline-saturated depositional setting. Deposition within shallow, warm supratidal/intertidal flat is suggested for this association.

\subsubsection{Mixed-intertidal-bar quartz arenites:}

This microfacies is recorded at the lower and the upper parts of Raha Formation. In the field, the association consists of 1.0-7.0 m thick of sandstones interbedded with $0.50 \mathrm{~m}$ thick shale layers. The sandstones are commonly hard, and exhibit laterally extensive open lensoidal geometry. The shale layers are thinly fissile and have grayish green colour. Petrographically, the sandstones are composed of dominant (95\%) quartz grains. These grains are medium to very fine grained, medium to poorly sorted and subangular to subrounded. They are medium to close packed and display point, long and concave-convex grain contacts indicating differential burial compaction. The majority of quartz grains are monocrystalline with even to slightly wavy extension. A few (2-3 $\%)$ yellowish green to brownish green glauconitic rounded detrital grains are scattered within the detritals. These detritals are cemented by a minor amount of faint gray calcareous material. These cementing materials commonly corrode into the quartz grain boundaries due to the mutual reactions between the grain boundaries (acidic $\mathrm{pH}$ nature) and the carbonate-rich pore-filling warm water (alkaline $\mathrm{pH}$ nature). Faint yellow ferruginous secondary cement is occasionally seen in some parts of the association, masking the original cement with yellow stains.

The bed-geometry, textural features, the intervening shale interbeds and the petrographic characteristics of this association assume deposition as successive sand bars within shallow mixed tidal flat of foreshore marine setting. The relatively poor sorting and variable roundness of the detritals signify variable detrital sources and depositional regimes.

\subsubsection{Non Clastic microfacies associations:-}

\subsubsection{Supratidal Dolomite wackestone, SMF25, FZ9}

This association is recorded at the lowermost part of the Raha Formation. It consists of $5.5 \mathrm{~m}$ thick of yellowish green (egg yellow) dolostone display irregularly-stacked fenestral-like lamination in terms of 2-4 mm spacing with entrapped elliptical small voids. Thin shale beds $(0.50$ to $1.0 \mathrm{~m})$ display laterally extensive sheetlike geometry and sharp irregular bed-contacts are sometimes recorded. Petrographically, the association is composed of a bulk-groundmass of interlocking mosaic of well developed coarse crystalline dolomite crystals exhibit homogenous appearance; usually have an almost uni-sized individuals and similar characteristics. Fine to very fine quartz grains are occasionally seen floating in the dolomitic groundmass forming about $10 \%$ of rock components(Fig 2d). The quartz grains display even and slightly wavy extension. Yellowish green and faint green, oval to kidney-like glauconite grains are occasionally disseminated, forming about $5 \%$ of the rock components. Reddish brown iron oxides pockets and stains are rarely seen in different parts of the association. Irregular and elongate patches of faint grey gypsum are seen occupying some parts within the dolomite groundmass.

The abundance of uni-sized homogeneous rhomboid dolomite crystals as a common groundmass suggests primary deposition of the dolomite crystals. Primary dolomites are commonly known from supratidal and warm intertidal depositional settings ([44]; [37]; [17]). Furthermore, the fenestral lamination is commonly reported from supratidal and intertidal flat facies (Tucker, 1981; Reading 1996). The gypsum facies, on the other hand, suggests a close nearness to super-saturated saline-rich sources together with high temperature conditions. The presence of detritals grains of fine and very fine quartz and glauconite assumes nearby source of such detritals, mostly beach bars or shallow marine bays. Deposition within shallow restricted supratidal marine settings is suggested for the present association. The association matches with SMF25 and FZ9 of [53] and [17]. 


\subsubsection{Intertidal lagoonal dolomitized wackestone association, SMF 23, FZ 8:}

This association is encountered at the basal parts of the Raha Formation. It consists of $13 \mathrm{~m}$ thick of hard massive faint yellow limestones interbedded with thinner shale beds. The limestones show laterally extensive sheet geometry with transitional gradual contacts with the shales above and below. The shales are 0.5$1.0 \mathrm{~m}$ thick with different reddish colouration and display laterally extensive sheet geometry, including a few scattered ill-defined molluscan debris. Petrographically, these limestones are consisting of homogenous pale grey lime-micrite forming the general framework of the present association. Very fine to coarse crystalline dolomite rhombs are scattered within the micrite matrix forming about $27 \%$ of the facies components. These indicate activities of $\mathrm{Mg}$-rich marine water that invaded the original micrite composition. Rare fine to very fine subangular quartz grains (2-3\%) of components) are sometimes seen displaying clear corroded grain boundaries against the lime-micrite.

The field stacking of the given association assumes close deposition of both limestones and shales together in successive stages depending upon the detritals input and sea level regime. Deposition might have been taken place within generally quiet, warm, saline-saturated marine setting of fluctuating sea-level and close to detrital mud-rich sources. An intertidal foreshore lagoonal setting, connected to the open sea is suggested for this association. Narrow connections to the open sea explain the presence of shell debris noticed in the shales. Possibly, the high salinity and inadequate circulation within the lagoons allowed no fauna to flourish. This association matches with SMF 23 and FZ 8 of [53] and [17].

\subsubsection{Fossiliferous wackestone, SMF 8/9, FZ 7:}

This association is recorded in the lower parts of the Raha Formation. In the field, the association consists of a $5.0 \mathrm{~m}$ thick of grey, medium hard limestone beds show sheet-like bed geometries and sharp planar bed-contacts and rich in animal bioturbations. Thin highly fissile shale beds of different red colours intercalate the limestones. Petrographically, the limestones are dominantly made up of a lime-mud (micrite) as a major constituent forming about $75 \%$ of the rock constituents. The micrite is slightly turbid with fine grey argillaceous material as well as faint brown ferruginous stains. The allochems generally constitute $25 \%$ of the rock. They are represented by different debris and complete ostracod shells, ill-defined scattered foraminiferal chambers and loosely packed pelecypods fragments, especially Ilymatogyra Africana and Ceratoctreon flabellatum. The boundaries of different allochems are clearly admixed within the rock matrix suggesting active micritization process. The internal cavities of the shells are entirely recrystallized into coarse crystalline mosaic calcite. Zoned euhedral dolomite crystals are recorded in some parts of the rock body documenting dolomitization by later Mg-rich pore filling water

Deposition within relatively shallow less energetic marine conditions under fluctuating sea-level is evidenced due to dominance of micrite/shale intercalation. However, the extensive animal burrows together with the many fossil remains encountered all suggest adequate circulation and life necessities. Deposition within a marine realm ranging between shallow shelf bays to inner marine shelf is suggested for this association. The SMF 8/9 and FZ 7 of [53] and [17] are most likely matching with the present association.

\subsection{The Abu Qada Formation:}

The microscopic investigation of eleven thin sections representing the Abu Qada Formation exposed at G. Nezzazat and G. Ekma sections revealed seven microfacies associations:

\subsubsection{Clastic microfacies associations:-}

\subsubsection{Glauconitic ferruginous siltstone}

This association is recorded at the upper part of Abu Qada Formation. In the field, the association is composed of $1.5 \mathrm{~m}$ thick greenish-brown, massive, hard, compact siltstone. The siltstones are laterally extensive, thinly laminated and exhibit large-scale undulating bed contacts. Petrographically, the association is composed of quartz silt-grains deposited with abundant glauconitic detritals grains of variable sizes and cemented by ferruginous cement. The quartz grains are constituted up to $80 \%$ of the rock composition. They are well-sorted, subangular to subrounded grains and display medium to close packing and the majority of the grains show point contacts and rarely long. The majority of quartz grains are monocrystalline-type of even to slightly undulose extension. Glauconite detritals grains are of yellowish green and faint green colors having rounded, oval to kidney-like grains. They are frequently scattered within quartz silts, forming about $15 \%$ of the rock components. Black to deep reddish brown iron oxides pockets are occasionally seen in different parts of the association. These detritals are first bounded with a fine clay matrix; however later ferruginous cement invaded the rock constituents with deep reddish brown color. The cement mostly corrodes and dissolves the quartz grain boundaries.

The textural and petrographic characteristics of this association suggest deposition within relatively less energetic conditions and far from the reach of coarse detritals. The fine lamination assume deposition by 
currents have the character of flow regime [23]. Moreover, the large-scale undulating bed-contacts are commonly developed within marine settings below wave base ([36]; [49]; [11]). Deposition might have taken place within quiet shallow marine setting, most likely, subtidal-inner shelf zone. Detrital glauconites may be derived from nearby quiet shelfal sediments or from underlying glauconitic-rich sediments. The association matches with SMF 4 and FZ 3/1 of [53] and [17].

\subsubsection{Intertidal flat feldspathic quartz arenite association}

This association is recorded at the upper part of Abu Qada Formation. In the field, the association is composed of $1.50 \mathrm{~m}$ thick hard, compact, massive sandstone. The sandstones exhibit sheet geometry with planar erosional bed-contacts. Petrographically, the association is composed of dominant (80-90\%) quartz grains. These grains are fine grained; moderately well sorted, subrounded to rounded grains, display different point, long and concave-convex contacts in clear of closed packing. The majority of quartz grains are of monocrystalline type of even and slightly wavy extension of quartz types of [20]. Feldspars are common, forming about $5 \%$ of the total rock volume, including alkali and plagioclase feldspars. These feldspars are fine grained and fresh (Fig 2e). These components are cemented by deep reddish brown ferruginous material with about $5 \%$ of the total rock volume (Fig 2e).

The presence of fresh and fine grained feldspars overweighs long transportation under arid conditions. Deposition in shallow intertidal flat is suggested for this association and the deposition of detrital-loads coming from nearby surroundings sand-bars.

\subsubsection{Foreshore lagoonal quartz arenite association:}

This association is recorded at the upper part of Abu Qada Formation. In the field, the association is composed of $1.50 \mathrm{~m}$ thick of brown, flaggy sandstones. These sandstones show uniform laterally extensive sheet-geometry with sharp planar erosive bed contacts. Petrographically, this association is composed of dominant $(\sim 90.00 \%)$ quartz grains deposited with a minor amount of calcareous cement. Both components display a unique textural pattern. The calcareous cement is in form of wide, very large mosaic crystalline calcite areas of well-developed rhmbohedral cleavages displaying marked twinkling. Within these mosaics, the detritals quartz grains are fully-immersed in poikilitic-like pattern, so that each well-developed calcite crystal encompasses a number of quartz-grains within. The quartz detritals are medium grained, well sorted and subrounded to well- rounded. The grains are dominantly of monocrystalline type displaying even to rarely undulose extension. The rims of the quartz grains are muchly corroded and embayed by the calcareous cement. The grains rarely show point contacts. Furthermore, well developed dolomite crystal-patches are many encountered in some parts of the association due to active role of pore-filling Mg-rich marine water resulted in the dolomitization of the original cement.

The textural characteristics of the detrital sands indicate the deposition of mature terrestrial load within an excessively carbonate-saturated depositional setting under relatively warm conditions. Deposition as beach sands within warm carbonate-saturated shallow fore-shore lagoons with relatively less circulation is most likely for this association.

\subsubsection{Non Clastic microfacies associations:-}

\subsubsection{Mid-shelf marine wackestone, SMF23, FZ1:}

This association is recorded at the upper part of Abu Qada Formation. In the field, the association consists $\sim 3.0 \mathrm{~m}$ thick of brown, hard limestone displaying gradational wavy bed-contacts. Petrographically, this association consists of a homogenous pale grey interlocking mosaic of coarse sparry-calcite forming the entire framework $(\sim 95 \%)$ of the association. However, a few patches of original dull grey-coloured micrite are recorded among the dominant sparite framework. Pale brown ferruginous materials are seen as clouds staining many parts of the general sparite groundmass. A few $(\sim 4.0 \%)$ euhedra of dolomite rhombs are scattered within the sparite framework.

The deposition of the rare fossiliferous lime-micrite suggests the deposition in shelf setting [17]. Deposition within relatively well-circulated, less energetic setting, generally below wave base of mid shelf is suggested for the given association. The SMF 23 and FZ 1 of [53] and [17] are most likely matching with the present association.

\subsubsection{Shelf bay - inner shelf packstone association, SMF10, FZ2:}

This association is recorded at the upper parts of Abu Qada Formation. In the field, it consists of 2.50 to $6.0 \mathrm{~m}$ thick of highly fossiliferous, hard, compact and argillaceous limestone, interbedded with fissile shale beds. The limestone beds display laterally extensive sheet-geometry with transitional gradation bed-contacts. Petrographically, this association is made up of a $\sim 30 \%$ lime-mud micrite, slightly turbid with fine grey argillaceous material. The allochems are generally common $(\sim 60 \%)$ and are represented by different pelecypod 
shells and shell fragments, accumulated in a medium-close packing within the common micrite matrix. The boundaries of the allochems are clearly admixed into the rock matrix. Mosaic of euhedral crystals of sparry calcite are commonly seen filling the fossil cavities. A few dolomite rhombs are recorded in some parts of the rock body, replacing the assimilated boundaries of shell fragments.

The dominance of micrite bulk composition together with the deposition of the large quantity of packed bivalves is suggests deposition within relatively quiet, less energetic marine conditions. This association was most-likely deposited within open circulated shelf bay and/or inner-shelf marine setting. The SMF 10 and FZ2 of [53] and [17] are most likely matching with the present association.

\subsubsection{Inner shelf packstone, SMF8, FZ7:}

This association is recorded at the upper part of Abu Qada Formation. In the field, it consists of 1.5 $3.0 \mathrm{~m}$ thick of hard, grey fossiliferous argillaceous limestones. These limestones generally display laterally extensive geometry with clear wavy undulating contacts. Petrographically, this association composed of a limemud micrite forming about $40 \%$ of the rock constituents. The allochems are generally common (60\%), including abundant debris and complete ostracod tests (Fig. 2g). Pelecypod fragments with micritized rims are seen scattered between the other allochems, floating within the common micrite matrix. A few dolomite crystals are recorded in some parts of the rock body.

Deposition within relatively quiet less energetic marine conditions is suggested here. However, the dominance of ostracods and other plenty fossil debris indicate good life conditions accompanying good circulation and other life necessities. Deposition within low energy, inner shelf just below wave base is suggested for this association. The SMF 8 and FZ 7 of [53] and [17] are most likely matching with the present association.

\subsubsection{Mid-outer marine shelf Oolitic-grainstone, SMF 15, FZ 8:}

This association is recorded at the upper part of Abu Qada Formation. In the field, it consists of 1.5 $2.00 \mathrm{~m}$ thick grey, hard thickly bedded limestones. The beds display laterally extensive geometry with gradational undulating bed contacts. Petrographically, the association is composed of allochems forming 90\% of the total rock volume. These allochems are entirely composed of vary-sized oolites, displaying very common fine concentric internal structure with large nuclei and thin cortices (Fig.2f). Internally, the oolites are made of fine homogeneous micrite, and many of them display clear micritized and dissolved parts within the rock cement. A few ooids display thin ferruginous cortices. They are very closely packed within a minor amount ( $10 \%$ ) coarse mosaic of sparite. Many of ooid-grains display point grain-to-grain contacts.

Oolitic-grainstones exhibit distinct concentric structures are commonly originated within ooid-shoals near outer platform margins or deep outer ramps ([53]; [17]). Micrite ooids are usually developed within marine subenvironments having the characters of mid-outer shelves or ramps [17]. This association was possibly deposited as oolitic micrite shoal within middle shelf marine conditions. The SMF15 and FZ 8 of [53] and [17] are most likely matching with the present association.

\subsection{Wata Formation:}

The microscopic investigation of sixteen thin sections representing the Wata Formation exposed at G. Nezzazat and G. Ekma sections revealed four non clastic microfacies associations without presence of siliciclastic associations.

\subsubsection{Non Clastic microfacies associations:}

\subsubsection{Mid-outer marine shelf wackestone, SMF23, FZ 1:}

This association is the most common in Wata Formation. It is recorded throughout different levels of the Wata Formation. In the field, the association is composed of $2.0-6.0 \mathrm{~m}$ thick units of brown, hard, compact, well-bedded cavernous dolomitic limestones. Petrographically, the association is originally composed of a dominant $(90 \%)$ lime-micrite that later recrystallized to form a wide areas of recrystallized microsparite. Some dolomite rhombs are seen in the expense of the lime-micrite. Rare fossil ghosts of pelecypods and ostracods are seen scattered in the micrite matrix.

The deposition of the rare fossiliferous lime-micrite suggests the deposition in shelf setting [17]. Deposition within relatively well-circulated, less energetic setting, generally below wave base of mid-outer shelf is suggested herein of the association. The SMF23 and FZ 1 of [53] and [17] are most likely matching with the present association.

\subsubsection{Mid-outer marine shelf Bioclastic packstone, SMF10, FZ7:}

This association is common in Wata Formation. It is recorded at the lower and upper part of Wata Formation at G. Ekma. In the field, the association is composed of $1.0-5.0 \mathrm{~m}$ thick hard, strongly burrowed and fossiliferous argillaceous limestone. Petrographically, these limestones are dominated $(\sim 80 \%)$ by different 
types of closely packed allochems. These allochems are represented by complete shells and fragments of pelecypods, ostracods, gastropods, echinoderms and foraminifera. These allochems are partially display micritized boundaries. These different allochems are embedded within micrite matrix forming about $20 \%$ of the total rock volume.

The presence of different types of closely packed allochems in the micrite matrix evidences the deposition at the mid-outer shelf setting [17]. The SMF10 and FZ7 of [53] and [17] are most likely matching with the present association.

\subsubsection{Outer marine shelf floatstone, SMF8, FZ7:}

This association is recorded at Wata Formation. In the field, the association is made up of $2.0 \mathrm{~m}$ thick dark grey, densely burrowed fossiliferous argillaceous limestones. Petrographically, these limestones are composed of rudaceous-sized pelecypod fragments not exceed $25 \%$ of the total rock components. These allochems are floated within a very common micrite matrix forming about $75 \%$ of the total rock volume. Dolomite euhedra $(\sim 2 \%)$ are occasionally scattered. The allochem-boundaries are partially micritized.

Deposition within relatively quiet less energetic marine conditions below normal wave base is suggested here due to dominance of micrite bulk composition and the rarity of detrital components (e.g. sands and silts). Deposition within outer shelf is suggested for this association. The SMF8 and FZ7 of [53] and [17] are most likely matching with the present association.

\subsubsection{Open marine-shelf Peloidal grainstone, SMF2, FZ3:}

This association is recorded at the lower and upper parts of the Wata Formation. In the field, the association is made up of $6.0 \mathrm{~m}$ thick compact, hard and fossiliferous argillaceous limestones. Petrographically, these limestones are composed of dominant (70\%) closely packed pellets having variable sizes (Fig. $2 \mathrm{~h}$ ). Shell fragments of pelecypods and echinoderms with micritized rims forming about $10 \%$ are inserted among the pellet framework. These allochems are generally embedded within a little micrite matrix (about 10\%), sometimes is partially recrystallized into fine sparite.

The deposition of an abundant peloids admixed with the fine bioclasts of pelecypods and echinoderms debris suggest deposition at relatively deeper basins most-likely open marine shelf /outer ramp setting [17]. The SMF2 and FZ3 of [53] and [17] are most likely matching with the present association.

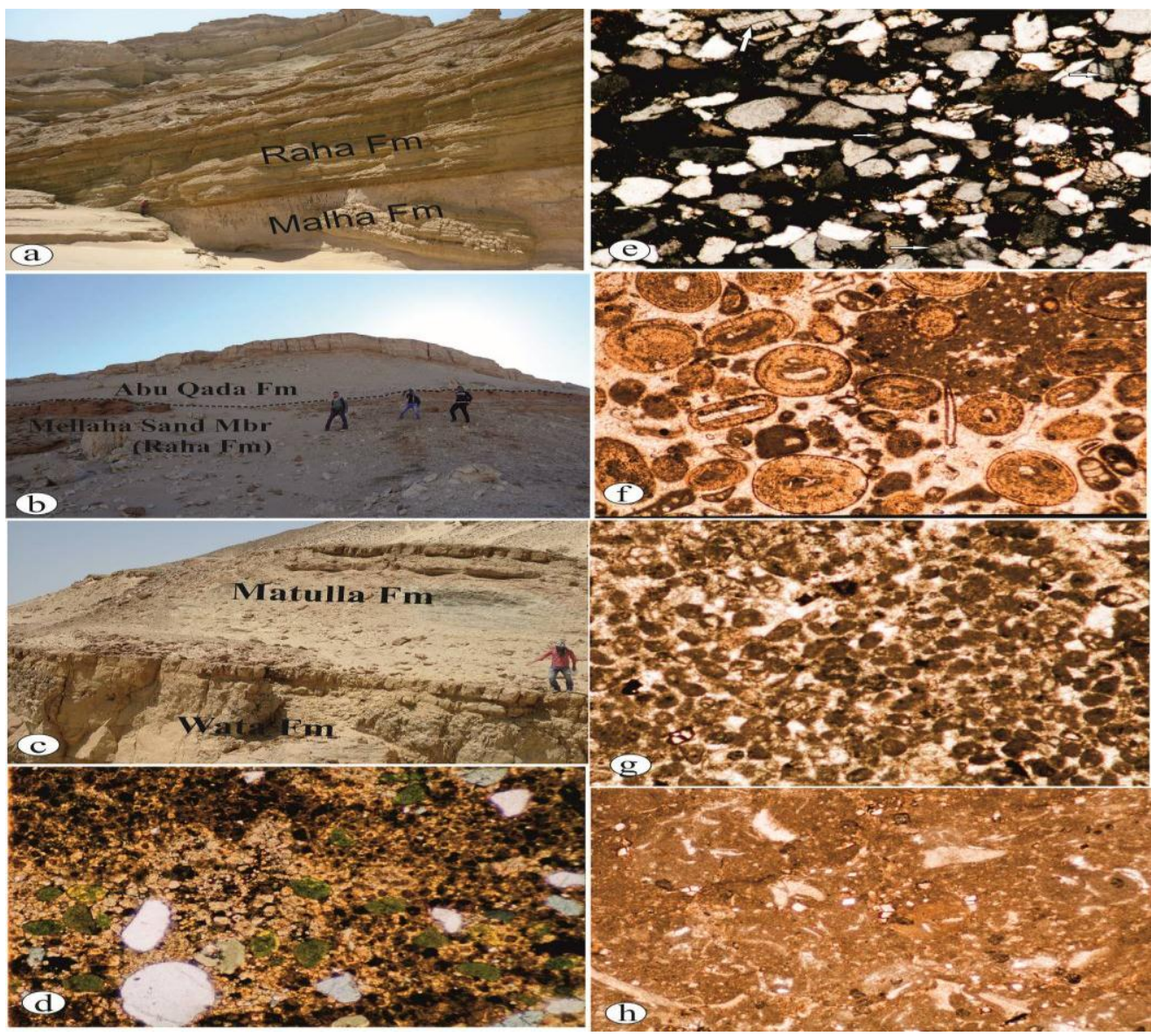


a- Contact between Malha Formation (Lower Cretaceous) and Raha Formation (Cenomanian) at G. Ekma. The view is looking to NE direction.

b- Contact between Mellaha Sand Member (Raha Formation) and Abu Qada Formation at G. Ekma area and the view is looking to NE direction.

c- Contact between Wata Formation (Turonian) and Matulla Formation (Coniacian-Santonian) at G. Ekma area.

d- Coarse crystalline dolomite rhombs with detrital quartz and glauconite, Dolomite wackestone association, Raha Formation, XPL (25X).

e- Closed packed quartz and feldspar grains cemented by ferruginous material, Feldspathic quartz arenite association, Abu Qada Formation, XPL (50X).Note: Feldspar grains (arrows)

f- Concentric ooids in sparitic cement, Oolitic-grainstone association, Abu Qada Formation, PPL (25X).

g- Close packed pellets cemented by fine sparitic cement, Peloidal grainstone association, Wata Formation, PPL (50X).

h- Ostracodal shells and pelecypod fragments packed and scattered in the original micritic matrix, Ostracodal packstone association, Abu Qada Formation, XPL (25X).

\section{Depositional Trends And Sedimentary Paleo-Environments:}

The detailed microfacies studies made for the Upper Cretaceous sedimentary rock units in the study area have enabled recognition of the different depositional environments involved in the evolution of each rock unit. The following are the main remarks on the depositional trends and paleo-environments prevailed during the evolution of the examined succession:-

\subsection{The Pre-Cenomanian Depositional Situation:}

The Pre-Cenomanian depositional situation was prevailed by a long-lasted fluvial conditions related to a wide fluvial net of meandering river system flowed over the entire parts of the north-eastern parts of Egypt including Sinai, depositing the fame unit of the Early Cretaceous Malha Formation ([1]; [4]; [13]). These widespread fluvial conditions resulted in the development of thick succession of point-bars and intervening paleosols of the Malha Formation. This formation is represented in the study area by the presence of successive sandstones and conglomerates as well as shales and paleosols, characterizing the upper part of Malha Formation. In generally, the Lower Cretaceous Malha Formation represents a long-lasted phase of continental sedimentation under humid climatic conditions ([14], [13]) before the submergence below the Upper Cretaceous (Cenomanian) sea.

\subsection{The Raha Formation:}

The Raha Formation (Cenomanian) is the lowermost rock unit in the examined succession. In the study area, the Raha Formation is a mixed siliciclastic/carbonate succession having an almost uniform thickness averaging $60.0 \mathrm{~m}$. The microfacies trends of the Raha Formation proved deposition under gradual marine deepening conditions related to a gradual sea-level rise of a subtle advancing sea started with the Cenomanian. The deposition started within the realm of shallow supratidal and intertidal sub-environments where dolostone and dismicrite facies rich in glauconites were deposited in the early stages, especially in the southern parts of G. Ekma (Fig. 4). The deepest marine setting in this episode lies with the depth of intertidal to shelf lagoons. The continuous Cenomanian sea-level rise resulted in the evolution of deeper sub-environments of shelf bays and reached the maximum sea-level rise during inner-shelf environment, where foraminiferal biomicrites and dismicrites were deposited. Toward the top of Raha Formation, a marked sea-level drop and land-ward shift of the sea-shore occurred marked by the deposition of supratidal sandstones with gypsiferous components and numerous ferruginous hard-crusts. This situation ends the deposition of the Raha Formation in the study area. Generally, the facies in southern parts were deposited in shallower marine settings than in the northern facies.

\subsection{Abu Qada Formation:}

Abu Qada Formation (Late Cenomanian-Early Turonian) successively overlies the Cenomanian Raha Formation. In the study area, the formation is 40.0 to $43.0 \mathrm{~m}$ thick. It is generally rich in siliciclastic facies, rapidly grown-upward into carbonate-dominated facies. With the Deposition of this formation, the shallow supratidal, intertidal and shelf lagoonal marine settings encountered below (top of Raha Formation) continued during the early stages of this formation as evidenced by the varicoloured shales, argillaceous limestones and sandstones recorded at the lower parts of this formation (Fig.4). However, these shallow marine facies gave-way to facies of deeper marine characters to develop through the continuous deposition of Abu Qada Formation. Therefore, a relatively thick mixed argillaceous/carbonate unit was deposited within the realm of shelf bays to inner-shelf marine settings, including bioclastic and ostracodal packstones. However, minor shallow marine fluctuations during the generally advancing sea-level rise are present as evidenced by intertidal sandstones were 
intervening the deeper facies. The gradual sea-level rise resulted in the dominance of shelf bays fossiliferous bioclastic packstones and sandstones. Toward the top parts of this formation, the sea-level reached maximum where dismicrite wackestones were deposited within deeper mid-shelf environment, especially at the northern parts of the study area (Fig.4).

\subsection{The Wata Formation:}

The Wata Formation (Middle-Late Turonian) overlies Abu Qada Formation. In the study area, the formation is 37.0 to $43.0 \mathrm{~m}$ thick. It is generally carbonate-dominated facies with a few thin siliciclastic intercalations. Generally, the formation represents a depositional episode of relatively deep marine environments related to a remarkable sea-level rise. The deposition involved the accumulation of bioclastic packstones and wackestones within deep marine mid/outer shelf conditions related to high sea-level settings. These conditions continued to dominate the entire depositional phase of Wata Formation. Different bioclastic packstones, floatstones and peloidal grainstone were deposited, representing the maximum sea-level rise during the depositional history of the Wata Formation.

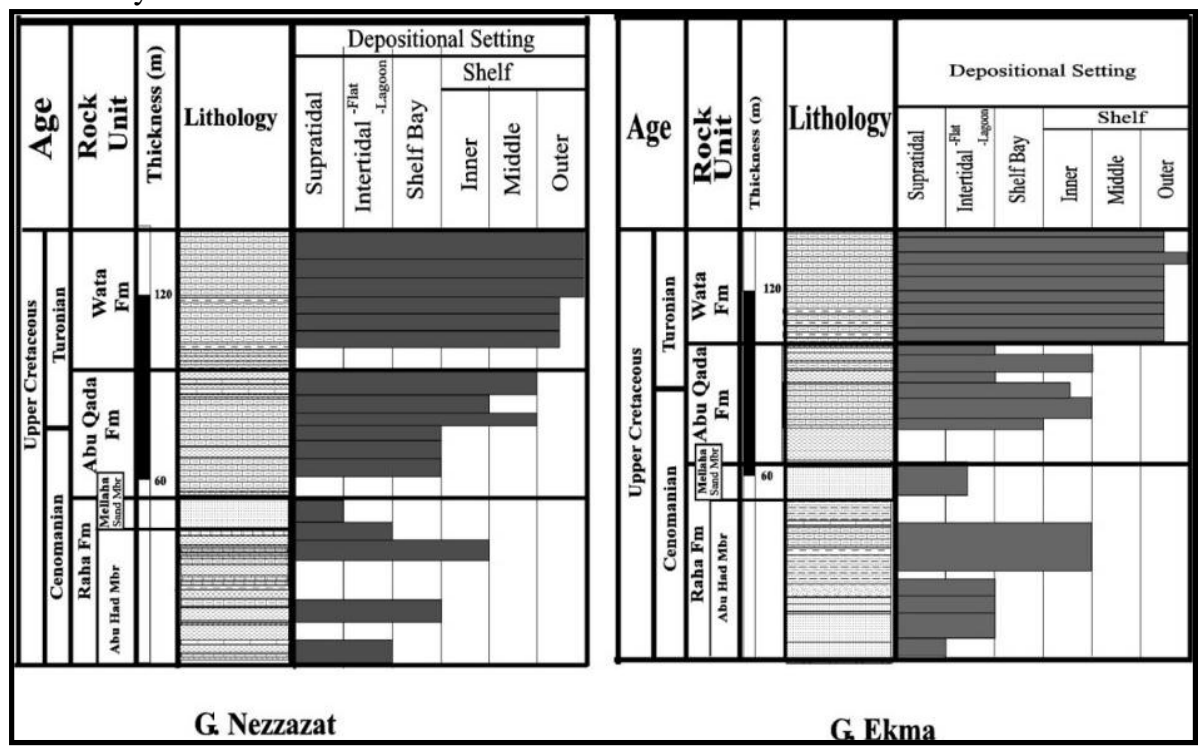

(Fig.4): Depositional setting and paleoenvironments in the Upper Cretaceous at G. Nezzazat and G. Ekma succession.

\section{References}

[1] A. M. Abdallah and A. Adindani, Notes on the Cenomanian-Turonian contact in the Galala Plateau, Eastern Desert, Egypt. Egy. J. Geol., 7, 1963, 67-70.

[2] G. I. Abdel-Gawad and A. Zalat, Some Upper Cretaceous macro-invertebrates from Gebel El-Hamra and Gebel Um Heriba, Mitla Pass, west central Sinai. -Proc. 1st Internat. Conf. Geol. Arab World, Cairo Univ. Egypt, 1992, 333-344.

[3] T. I. Anan, A. El-Shahat, A. Genedi, and M. Grammer, Depositional environments and sequence architecture of the Raha and Abu Qada formations (Cenomanian-Turonian), west central Sinai, Egypt. J. Afr. Ear. Sci., 82, 2013, 54-69.

[4] M. G. Barakat, M. Darwish and A. N. El Bakooky, Lithostratigraphy of the post Carboniferous-pre Cenomanian in west central Sinai and Gulf of Suez, Egypt. In: EGPC $8^{\text {th }}$ Expl. Conf., 1986, 1-15.

[5] Y. Bartov and G. Steinitz, The Judea and Mount Scopus groups in the Negev and Sinai with trend surface analysis of the thickness data. Isr. J. Ear. Sci. 28, 1977, 119-148.

[6] Y. Bartov, Z. Lewy and G. Steinitz, Mesozoic and Tertiary stratigraphy, paleogeography and structural history of the Gebel Areif el Naqa Area, Eastern Sinai. Isr. J. Ear. Sci. 29, 1980a, 114-139.

[7] Y. Bartov, Z. Lewy, G. Steinitz, and I. Zak, Mesozoic and Tertiary stratigraphy, paleogeography and structural history of the Gebel Areif en Naqa area, eastern Sinai. Isr. J. Ear. Sci., 29, 1980b, 114-139.

[8] J. Bauer, J. Kuss and T. Steuber, Sequence architecture and carbonate platform configuration (Late Cenomanian-Santonian), Sinai, Egypt. Sediment., 50, 2003, 387-414.

[9] J. Bauer, A. M. Marzouk, T. Steuber and J. Kuss, Lithostratigraphy and biostratigraphy of the Cenomanian-Santonian strata of Sinai, Egypt. Cret. Res., 22, 2001, 497-526.

[10] A. Bein and G. Givertzman, A Mesozoic fossil edge of the Arabian plate along the Levant coastline and its bearing on the evolution of the eastern Mediterranean. In: Biju-Duval, B., Montadert, L. (Eds.), Structural History of the Mediterranean Basins. Edition Technip, Paris, 1977, 95-110.

[11] P. J. Brenchley, Storm influenced sandstone beds. Modern Geology, 9, 1985, 369-396.

[12] R. J. Dunham, Classification of carbonate rocks according to their depositional texture, in W. E. Ham, ed., Classification of Carbonate Rocks: Tulsa, OK, American Association of Petroleum Geologists Memoir, 1, 1962, 108-121.

[13] F. M. El-Fawal, Sedimentologic studies of the Pre-Cenomanian rocks in East-Central Sinai, Egypt. Ph.D. Thesis, Geol. Dept., Fac. Sci., Suez Canal Univ. Ismailia, 1988.

[14] E. M. El Shazly and M. Krs, Paleogeography and paleomagnetism of the Nubian Sandstone, Eastern Desert, Egypt. Geol. Rundsch., 62, 1973, 212-225. 
[15] A. F. Embry and J. E. Klovan, A Late Devonian reef tract on northeastern Banks Island, N.W.T.: Bul. Canadian Petroleum Geol., 19: 1971): 730-781.

[16] E. Flügel, Microfacies Analysis of Limestones. Springer-Verlag, Berlin, 1982.

[17] E. Flügel, Microfacies of Carbonate Rocks. Springer, Berlin, 2004.

[18] R. L. Folk, Practical petrographic classification of limestone. -Bull. AAPG, 43, 1959, 1-38.

[19] R. L. Folk, Spectral subdivision of limestone types. In: Hamed W. E. (ed): Classification of carbonate rocks. (-Bull. A.A.P.G., Mem. No. I, 1962) 62-84.

[20] R. L. Folk, Petrology of Sedimentary Rocks. -Hemphill, Publ. Co., 1980.

[21] Z. Garfunkel and Y. Bartov: The tectonics of the Suez Rift. Geol. Surv. Isr. Bull., 71, 1977, $1-44$

[22] M. A. Ghorab, Abnormal stratigraphic features in Ras Gharib oilfields, Egypt. In: 3rd Arab Petroleum Congress, Alexandria, Egypt, 1961: 1-10.

[23] J. C. Harms, J. B. Southard, D. R. Spearig, and R. G. Walker Depositional environment as interpreted from primary sedimentary structures and classification sequences. Soc. Econ. Paleo. Min. short course 2: 1975, 161 p.

[24] H. Hataba, and G. Ammar, Comparative stratigraphic study on the Upper Cenomanian- Lower Senonian sediments between the Gulf of Suez and Western Desert, Egypt. - Proc. $10^{\text {th }}$ Petroleum Exploration and Production Conference, $1990,1-16$.

[25] A. S. Kassab and M. M. Ismael, Upper Cretaceous invertebrate fossils from the area northeast of Abu Zuneima, Sinai, Egypt. Neues Jahrbuch für Geol. Palaeo., Abhandlungen 191, 1994, 221-249.

[26] A. S. Kassab, Cenomanian-Turonian boundary in the Gulf of Suez region, Egypt: towards an interregional correlation, based on ammonites. Geol. Soc. Egy., Spec. Publ., 2, 1996, 61-98.

[27] A. S. Kassab and N. A. Obaidalla, Integrated biostratigraphy and inter-regional correlation of the Cenomanian- Turonian deposits of Wadi Feiran, Sinai, Egypt. Cret. Res., 22, 2001, 105-114.

[28] M. T. Kerdany and O. H. Cherif, Mesozoic. In R. Said (Ed.) The Geology of Egypt. Rotterdam, Balkema, 1990.

[29] M. Kora, Khalil, and M. Sobhy, Stratigraphy and microfacies of some Cenomanian-Turonian successions in the Gulf of Suez region, Egypt. Egy. J. Geol., 45(1), 2001, 413-439.

[30] M. Kora and A. Genedi, Lithostratigraphy and facies development of Upper Cretaceous carbonates in east central Sinai, Egypt. Facies, 32, 1995, 223-236.

[31] M. Kora, and H. Hamama, Biostratigraphy of the Cenomanian -Turonian of Gabal Gunna, southeastern Sinai. Mans. Sci. Bull. 14, 1987, 289-301.

[32] M. Kora, A. Shahin, and A. Semiet, Biostratigraphy and paleoecology of some Cenomanian successions in the west central Sinai, Egypt. Neues Jahrbuch für Geol. und Palaeo, Monatshefte, 1994, 597-617.

[33] J. Kuss, Facies and stratigraphy of Cretaceous limestones from northeast Egypt, Sinai, and southern Jordan. Proc. $1^{\text {st }}$ Internat. Conf. Geol Arab World, Cairo University, 1992, 283-301.

[34] M. M. Mandur, Lithostratigraphy and biostratigraphy of the upper Cretaceous succession of Southeastern Sinai, Egypt. Egyp. J. Petroleum, 20, 2011, 89-96.

[35] W. J. Plumley, G. A. Risley, R. W. Graves and M. E. Kaley, Energy index for limestone interpretation and classification. AAPG Mem., 1, 1962, 85-107.

[36] P. E. Potter, Sand bodies and sedimentary environments: A Review. AAPG, 51(3), 1967, 337-365.

[37] H. G. Reading, Sedimentary Environments: Processes, Facies and Stratigraphy. Blackwell Science, Oxford, England, 1986.

[38] S. G. Saber, Depositional facies and paleoenvironments of the Cenomanian- Santonian succession in Gabal Ekma, west central Sinai, Egypt. Egyp. J. Geol., 46, 2002, 471-494.

[39] R. Said, The Geology of Egypt. Elsevier, Amsterdam, 1962.

[40] R. Said, Explanatory notes to accompany the geological map of Egypt. Geological Survey of Egypt, 56, 1971, 1-123.

[41] M. D. Samuel, O. H. Cherif and A. I. M. Akarish, Contribution to Cretaceous-Early Tertiary stratigraphy, paleogeography and tectonism of central Sinai. Egyp. J. Geol., 42 (2), 1998, 393-417.

[42] M. D. Samuel, A. A. Ismail, A. I. M. Akarish and A. H. Zaky, Upper Cretaceous stratigraphy of the Gebel Somar area, north-central Sinai, Egypt. Cretaceous Res., 30, 2009, 22-34.

[43] M. G. Sayed, Paleontologic studies of the upper Cretaceous rocks of Gebel Nezzazat area, Eastern Coast of the Gulf of Suez, Egypt. Unpub. Ph.D. Thesis, Geol. Dept., Fac. Sci., Cairo Univ., Egypt, 1990.

[44] R. C. Selley, Ancient Sedimentary Environments. Chapman and Hall, 1980.

[45] A. Shahin, Oxygen and carbon isotopes and foraminiferal biostratigraphy of the Cenomanian-Turonian succession in Gabal Nezzazat, southwestern Sinai, Egypt. Rev. Paléobiol., Genève, 26, 2007, 359-379.

[46] A. Shahin, Cenomanian-Turonian ostracods from Gebel Nezzazat, southwestern Sinai, Egypt, with observation on $\delta 13 C$ values and the Cenomanian-Turonian boundary. J. Micropaleo, 10(2), 1991, 133-150.

[47] A. Shahin, and M. Kora, Biostratigraphy of some Upper Cretaceous successions in the eastern Central Sinai, Egypt. Neues Jahrbuch für Geologie und Paläontologie, Monatshefte, 11, 1991, 671-692.

[48] M. Shirav, Stratigraphy and structure of Quseib graben. northern Gulf of Eilat. - G.S.I. Annual Meeting, Abstracts, 1985 , 1- 2.

[49] D. P. Swift, A. JR. Figueiedo, G. L. Freeland, and G. F. Oertel, Hummocky cross-stratification and Megaripples: A Geological double standard. J. Sed. Pet., 53(4), 1983, 1295-1317.

[50] N. Tewfik and Z. Ebeid, On stratigraphy of Upper Cretaceous in the Gulf of Suez region, Egypt. Revista Espanola de Micropaleont. 3, 1975, 11-33.

[51] M. E. Tucker, Sedimentary Petrology. An introduction. Blackwell Sci., Publ., Oxford., 1981.

[52] H. A. Wanas, Cenomanian rocks in the Sinai Peninsula, northeast Egypt: facies analysis and sequence stratigraphy. J. Afr. Earth Sci., 52, 2008, 125-138.

[53] J. L. Wilson, Carbonate Facies in Geologic history. Springer-Verlag, New York, Heidelberg, Berlin, 1975.

[54] A. Ziko, M. Darwish and S. Eweda, Late Cretaceous-early Tertiary stratigraphy of the Themed area, east central Sinai, Egypt. Neues Jahrbuch für Geologie und Palaontologie, Monatshefte, 1993, 135-149. 